Gabriela Jyz $\dot{z}^{1}$

\title{
NOWELIZACJA USTAWY PRAWO O SZKOLNICTWIE WYŻSZYM W ZAKRESIE ORGANIZACJI I FUNKCJONOWANIA SPRAW WŁASNOŚCI INTELEKTUALNEJ W SZKOŁACH WYŻSZYCH (ZAGADNIENIA WYBRANE)
}

\section{Uwagi ogólne}

Nowelizacja ustawy z dnia 27 lipca 2005 r. - Prawo o szkolnictwie wyższym, ${ }^{2}$ dokonana ustawą z dnia 11 lipca 2014 r. o zmianie ustawy - Prawo o szkolnictwie wyższym oraz o zmianie niektórych innych ustaw, ${ }^{3}$ która weszła w życie 1 października 2014 r., zawiera m.in. regulację prawną określaną popularnie mianem „uwłaszczenia naukowców”, która już na etapie konsultacji środowiskowych była przedmiotem krytyki, a i obecnie nie rodzi nazbyt przychylnych komentarzy środowisk uczelni wyższych, w tym zwłaszcza teoretyków prawa własności intelektualnej. Przypomnieć należy, iż w uzasadnieniu konieczności dokonania tych zmian w ustawie wskazano na to, że polska gospodarka w niezadowalający sposób dotychczas wykorzystuje w praktyce wyniki badań naukowych, co w konsekwencji powoduje niską innowacyjność polskich przedsiębiorstw. Brak jest transferu rezultatów prac badawczych i rozwojowych oraz know-how ze szkół wyższych do gospodarki.

\section{Dotychczasowy stan prawny w zakresie organizacji i funkcjonowania spraw własności intelektualnej w szkołach wyższych}

Nie ulega wątpliwości, iż działalność naukowa, realizowana w zasadniczym zakresie w szkołach wyższych, winna stanowić fundament dla rozwoju gospodarki opartej na wiedzy. W związku z tym obecnie funkcje uczelni wyższych są znacznie

Doktor habilitowana, profesor Politechniki Opolskiej, sędzia NSA Izba Gospodarcza.

Tekst jedn. Dz.U. z 2012 r., poz. 572 z późn. zm.; dalej powoływana jako u.p.o.s.w.

Dz.U. z 2014 r. poz. 1198. 
szersze niż miało to miejsce w przeszłości. Do funkcji fundamentalnych, tj. funkcji kształcenia studentów i kadry naukowej, prowadzenia badań naukowych, dołączyła funkcja aktywnego uczestniczenia w tworzeniu gospodarki opartej na wiedzy. Działalność naukowa pracowników naukowych i naukowo-dydaktycznych otrzymuje nowy wymiar - działalności użytecznej ekonomicznie w aspekcie rozwoju gospodarki państwa. Podkreślić należy, iż problematyka twórczości naukowej w wyższych uczelniach, jej organizacji i funkcjonowania oraz jej gospodarczego wykorzystania, w tym zwłaszcza w przemyśle, była przedmiotem bacznej uwagi ustawodawcy oraz zarówno praktyków, jak i teoretyków także przed obecną, omawianą w niniejszym opracowaniu, nowelizacją ustawy - Prawo o szkolnictwie wyższym. Zagadnienie to zresztą słusznie postrzegane jest jako rozległe, niełatwe i rodzące konieczność pogodzenia interesów uczelni wyższej jako pracodawcy pracownika - twórcy, z interesami samych twórców, którzy mają niezaprzeczalne prawo do efektów swojej pracy twórczej (naukowo-badawczej), w tym do czerpania z niej korzyści majątkowej. Nie można także tracić z pola widzenia interesów przedsiębiorców, biznesmenów, którzy są lub będą odbiorcami efektów wytworzonych w uczelniach wyższych przedmiotów własności intelektualnej, rozumianej szeroko jako zarówno utwory w pojęciu prawa autorskiego, jak i przedmioty własności przemysłowej.

Siłą rzeczy w tak krótkim opracowaniu nie można zamieścić zbyt rozległego rysu historycznego regulacji prawnej dotyczącej zagadnień organizacji i funkcjonowania spraw własności intelektualnej w szkołach wyższych. $Z$ tej przyczyny w opracowaniu skupiono się na regulacjach bezpośrednio poprzedzających nowelizację ustawy - Prawo o szkolnictwie wyższym, choć czasami nie sposób uniknąć porównań z jeszcze wcześniejszymi rozwiązaniami prawnymi.

Regulacje prawne dotyczące dzieł intelektualnych stworzonych przez pracowników uczelni wyższych znajdowały się do tej pory ${ }^{4}$ głównie w trzech zasadniczych ustawach, tj.: w ustawie z dnia 4 lutego 1994 r. o prawie autorskim i prawach pokrewnych, ${ }^{5}$ ustawie z dnia 30 czerwca 2000 r. Prawo własności przemysłowej ${ }^{6}$ oraz w ustawie z dnia 27 lipca 2005 r. Prawo o szkolnictwie wyższym. ${ }^{7}$

W ustawie o prawie autorskim i prawach pokrewnych ochronie poddano utwory, przy czym ustawodawca posługując się w jej regulacjach terminem ,utwór naukowy" nie daje jego legalnej definicji. Sięgając do stanowiska doktryny można posłużyć się definicją skonstruowana przez J. Bartę, która brzmi: ,przez utwór naukowy należy rozumieć takie utwory (art. 1 ust. 1), które stanowią rezultat naukowego procesu poznawczego i które równocześnie, w swej podstawowej funkcji komunikacyjnej, są zorientowane nie na «siebie», jak utwory artystyczne, lecz na przedstawienie obiek-

\footnotetext{
Czyli do wejścia w życie omawianej nowelizacji ustawy - Prawo o szkolnictwie wyższym.

Tekst jedn. Dz.U. z 2006 r. Nr 90, poz. 631 z późn. zm., dalej powoływana jako u.o.p.a.

Tekst jedn. Dz.U. z 2013 r. poz. 1410; dalej powoływana jako u.p.w.p.

Tekst jedn. Dz.U. z 2012 r. poz. 572 z późn. zm.
} 
tywnie istniejącej rzeczywistości." ${ }^{8}$ Podobnie jak pozostałe typy utworów utwory naukowe podlegają ochronie autorskoprawnej od momentu ustalenia bez konieczności dopełnienia jakichkolwiek formalności. Art. 14 u.o.p.a. stanowi, że: „1. Jeżeli w umowie o pracę nie postanowiono inaczej, instytucji naukowej przysługuje pierwszeństwo opublikowania utworu naukowego pracownika, który stworzył ten utwór w wyniku wykonywania obowiązków ze stosunku pracy. Twórcy przysługuje prawo do wynagrodzenia. Pierwszeństwo opublikowania wygasa, jeżeli w ciągu sześciu miesięcy od dostarczenia utworu nie zawarto z twórcą umowy o wydanie utworu albo jeżeli w okresie dwóch lat od daty jego przyjęcia utwór nie został opublikowany." (ust. 1). Instytucja naukowa może, bez odrębnego wynagrodzenia, korzystać z materiału naukowego zawartego w utworze, o którym mowa w ust. 1, oraz udostępniać ten utwór osobom trzecim, jeżeli to wynika z uzgodnionego przeznaczenia utworu lub zostało postanowione w umowie." (ust. 2). Jak podkreśla się w literaturze przedmiotu przepis art. 14 u.o.p.a. stanowi lex specialis w stosunku do unormowań zawartych w art. 12 ustawy, a dotyczących utworów pracowniczych w ogólności i zawiera postanowienia korzystniejsze dla pracowników - twórców utworów naukowych, np. w zakresie prawa do wynagrodzenia. Nadto normy zawarte w tym przepisie mają charakter względnie obowiązujący, ponieważ strony (pracownik naukowy i instytucja naukowa) mogą w umowie o pracę uchylić prawo instytucji do pierwszej publikacji utworu naukowego, który powstał w wyniku wykonywania obowiązków ze stosunku pracy. Jednak samo prawo pierwszego wydania utworu naukowego przez instytucję naukową jest prawem majątkowym o charakterze bezwzględnym, co powoduje, iż pracodawca (instytucja naukowa) może wystąpić przeciwko każdemu, kto z naruszeniem jego prawa opublikował dzieło naukowe, bez względu na to czy twórca wyraził na to zgodę. ${ }^{9}$ Natomiast uprawnienia instytucji naukowej, będącej pracodawcą twórcy, wynikające $z$ treści art. 14 ust. 2 u.o.p.a. są uprawnieniami majątkowymi o charakterze względnym i są skuteczne tylko wobec podmiotu autorskich praw majątkowych. Pojęcie „korzystanie z utworu naukowego” nie zostało przez ustawodawcę sprecyzowane. Jak się wydaje obejmuje ono korzystanie przez pracodawcę zarówno z utworu jako takiego, jak i z materiału naukowego zawartego w tym utworze na potrzeby własne instytucji naukowej (naukowe i dydaktyczne) oraz udostępnienie osobom trzecim w takich przypadkach i w takim zakresie, który wynika z umowy zawartej przez instytucję naukową z twórcą. Zaakcentować także należy, iż przyznanie instytucji naukowej (w tym uczelni wyższej) prawa pierwszeństwa do opublikowania utworu naukowego, które może być zrealizowane przez instytucję naukową gdy sam twórca (pracownik instytucji naukowej) podejmie de-

J. Barta, (w:) J. Barta, M. Czajkowska-Dąbrowska, Z Ćwiąkalski, R. Markiewicz, E. Traple, Komentarz do ustawy o prawie autorskim i prawach pokrewnych, wyd. 1, Warszawa 1995, s. 129. Idem oraz R. Markiewicz, (w:) J. Barta (red.), System prawa prywatnego. Prawo autorskie, t. 13, Warszawa 2003, s. 23-24 piszą szerzej o rozgraniczeniu w dziele naukowym elementów chronionych i niechronionych.

9 J. Barta, (w:) J. Barta, M. Czajkowska-Dąbrowska, Z Ćwiąkalski, R. Markiewicz, E. Traple, Komentarz..., op. cit. s.130 in. 
cyzję o opublikowaniu utworu, nie ma charakteru autorskiego prawa majątkowego, a zatem nadal twórca (pracownik uczelni) pozostaje podmiotem całości praw autorskich do utworu naukowego (osobistych i majątkowych). ${ }^{10}$

Wskazane regulacje prawne wywołują uzasadnione słowa krytyki, zwraca się mianowicie uwagę na następujące mankamenty tej regulacji prawnej:

- przepis ten w polskich realiach często jest przepisem martwym, z uwagi na aktualne możliwości wydawnicze instytucji naukowych, w tym także uczelni wyższych,

- terminy określone w art. 14 u.o.p.a. (6 miesięcy na skorzystanie przez instytucję naukową $\mathrm{z}$ możliwości pierwszeństwa $\mathrm{w}$ opublikowaniu pracy naukowej oraz 2 lata na dokonanie publikacji) są zbyt długie, co powodować może znaczne opóźnienia $\mathrm{w}$ rozpowszechnianiu wyników badań naukowych, a w konsekwencji nie sprzyja wykorzystywaniu tych wyników dla stworzenia nowoczesnej gospodarki opartej o wiedzę,

- dla pracowników naukowych często korzystniejsze jest publikowanie swoich prac w wydawnictwach o zasięgu ogólnokrajowym i renomowanych naukowych czasopismach, a nie w wydawnictwach uczelnianych o zasięgu lokalnym. Jest to również korzystniejsze w gruncie rzeczy dla samych szkół wyższych z uwagi na system punktowy oceny osiągnięć naukowych. ${ }^{11}$

Należy także zwrócić uwagę na treść art. 15a u.o.p.a., który odnosi się do studenckich prac dyplomowych będących utworami, a który brzmi: „Uczelni w rozumieniu przepisów o szkolnictwie wyższym przysługuje pierwszeństwo w opublikowaniu pracy dyplomowej studenta. Jeżeli uczelnia nie opublikowała pracy dyplomowej w ciągu 6 miesięcy od jej obrony, student, który ją przygotował, może ją opublikować, chyba że praca dyplomowa jest częścią utworu zbiorowego."

Odnosząc się do regulacji prawnych zawartych w ustawie $\mathrm{z}$ dnia 30 czerwca 2000 r. - Prawo własności przemysłowej, podkreślić należy, iż przepisy tej ustawy nie zawierają odmiennych regulacji prawnych dotyczących przedmiotów własności przemysłowej tworzonych przez pracowników uczelni wyższych. Zgodnie z art. 11 ust. 3 u.p.w.p.: „W razie dokonania wynalazku, wzoru użytkowego albo wzoru przemysłowego $\mathrm{w}$ wyniku wykonywania przez twórcę obowiązków ze stosunku pracy albo z realizacji innej umowy, prawo, o którym mowa w ust. 1, przysługuje pracodawcy lub zamawiającemu, chyba że strony ustaliły inaczej." Ust. 1 tegoż artykułu ustawy statuuje prawo do patentu na wynalazek, prawo ochronne na wzór użytkowy i prawo rejestracji wzoru przemysłowego. $\mathrm{Z}$ mocy art. 201 u.p.w.p. zasady te do-

10 Szerzej piszą: M. Bukowski, Podmiot prawa autorskiego, „Przegląd Ustawodawstwa Gospodarczego” 1994, nr 11, s. 9; A. Kędzierska-Cieślak, Pierwszeństwo instytucji naukowej do opublikowania utworu jej pracownika, „Państwo i Prawo” 1996, z. 8-9, s. 80. lazczość i Ochrona Własności Intelektualnej, Kielce 2010, z. 34, s. 112-114. 
tyczą także topografii układów scalonych. Zarówno przepisy poprzednio obowiązującej ustawy o wynalazczości, ${ }^{12}$ jak i aktualnie obowiązującej ustawy - Prawo własności przemysłowej nie posługują się expressis verbis terminem ,pracownik”. Mówią natomiast o wynalazku, wzorze użytkowym, wzorze przemysłowym i topografii układu scalonego dokonanym przez twórcę „,w wyniku wykonywania obowiązków ze stosunku pracy", co jest opisowym określeniem projektu dokonanego przez pracownika. Jak podkreśla się w doktrynie, ponieważ ustawodawca nie definiuje w prawie własności przemysłowej terminu ,,pracownik”, rodzą się wątpliwości co do jego rozumienia na gruncie tego prawa. ${ }^{13}$ Aktualnie jednak w polskiej doktrynie dominuje pogląd, iż należy odstąpić od rozciągnięcia pojęcia ,pracownik” na osoby świadczące pracę w ramach stosunków służbowych (np. żołnierzy zawodowych, policjantów, funkcjonariuszy służby więziennej itp.).

Stosownie do uregulowań zawartych w art. 2 Kodeksu pracy ${ }^{14}$ pracownikiem jest osoba fizyczna zatrudniona na podstawie umowy o pracę, powołania, wyboru, mianowania lub spółdzielczej umowy o pracę. Trzeba zaznaczyć, że samo istnienie podstawy (np. wyboru, mianowania), jeśli nie łączy się z nim zatrudnienie w ramach stosunku pracy, nie wystarcza do uznania danej osoby za pracownika. Za taką interpretacją art. 11 ust. 3 u.p.w.p przemawia fakt, iż prawo do uzyskania patentu na wynalazek i do uzyskania pozostałych praw wyłącznych na przedmioty własności przemysłowej, przysługujące pracodawcy jest wyjątkiem od zasady patentu dla wynalazcy, a więc w myśl zasady exceptiones non sunt extendendae nie można go interpretować rozszerzająco.

Obowiązki pracownicze ciążą na pracowniku tylko w czasie trwania stosunku pracy. Zatem po jego ustaniu dokonane wynalazki nie mogą być uznane za powstałe w wyniku wykonywania obowiązków ze stosunku pracy. Polskie prawo własności przemysłowej nie daje podstawy do rozciągnięcia przepisów o wynalazkach pracowniczych na wynalazki dokonane przez byłego pracownika. Niemniej jednak strony (pracodawca i pracownik) mogą tę kwestię uregulować w umowie o zakazie konkurencji, stosownie do treści art. $101^{1}$ i nast. Kodeksu pracy. Wynalazek można uznać za dokonany w wyniku wykonywania obowiązków ze stosunku pracy, jeśli: 1) obowiązek twórczości wynalazczej pracownika wynika z ustawy lub z umowy, 2) przedmiot wynalazku jest w tych obowiązkach skonkretyzowany: poleceniem służbowym, indywidualnym zakresem obowiązków pracownika, planem prac badawczych itp. ${ }^{15}$ Jak podkreśla K. Szczepanowska-Kozłowska w przypadku niektórych kategorii pracowników jednostek naukowych obowiązek twórczości wynika wprost z ustawy. W konsekwencji na pracowników tych mocą ustaw nałożono obowiązek działalno-

\footnotetext{
12 Ustawa z dnia 19 października 1972 r. o wynalazczości (tekst jedn. Dz.U. z 1993 r. Nr 26, poz. 117 z późn.zm.).

13 Szerzej piszę na ten temat w monografii: G. Jyż, Prawo do wynagrodzenia za projekty wynalazcze, Katowice 2003, s. 105 in.

14 Ustawa z dnia 26 czerwca 1974 r. Kodeks pracy (tekst jedn. Dz.U. z 2014 r. poz. 1502 z późn. zm.).

15 A. Szewc, Wynagrodzenia twórców i wykonawców w prawie autorskim i wynalazczym, Sopot 1999, s. 71; G. Jyż, Wynagrodzenia..., op. cit., s. 107 i powołana tam literatura przedmiotu.
} 
ści twórczej, nawet jeżeli nie został on bezpośrednio zawarty w postanowieniach zawartych w umowie pomiędzy jednostką naukową a pracownikiem. Decydujące dla oceny istnienia bądź braku obowiązku twórczości jako obowiązku nałożonego ustawowo jest stanowisko, na którym pracownik jest zatrudniony. W uczelniach wyższych, zgodnie z treścią art. 111 ust. 1 pkt 2) i ust. 2 u.p.o.s.w., obowiązek twórczości nałożony został na pracowników naukowych i naukowo-dydaktycznych, ale już nie na pracowników dydaktycznych oraz pozostałych pracowników posiadających status nauczycieli akademickich (np. dyplomowani bibliotekarze oraz dyplomowani pracownicy dokumentacji i informacji naukowej - art. 108 pkt 4) u.p.o.s.w.). ${ }^{16}$

Przechodząc do dotychczasowych regulacji zawartych w ustawie Prawo o szkolnictwie wyższym podkreślić należy, że przepisy tejże ustawy nie zawierały - do czasu nowelizacji w 2014 r. - szczególnych unormowań odnoszących się do pracowniczych utworów tworzonych przez pracowników naukowych i studentów, poza wskazanymi wyżej normami zawartymi w ustawie o prawie autorskim i prawach pokrewnych. Kwestia organizacji i funkcjonowania praw własności intelektualnej w szkole wyższej, przed wejściem w życie omawianej nowelizacji ustawy Prawo o szkolnictwie wyższym, normowana była w uczelniach przede wszystkim w regulaminach korzystania z własności intelektualnej, przyjmowanych uchwałami senatów uczelni. Zakres podmiotowy i przedmiotowy tych aktów był na ogół określony dość szeroko. Zakres podmiotowy obejmował zarówno pracowników uczelni (nie tylko pracowników naukowych i naukowo-dydaktycznych), osoby nie pozostające z uczelnią w stosunku pracy, w tym: doktorantów, studentów, stażystów i stypendystów (jeśli tak stanowiła umowa), inne podmioty (jeśli tak stanowiła umowa). Zakres przedmiotowy określano jako zastosowanie postanowień regulaminów do wyników prac intelektualnych, a w szczególności do: a) dokonanych w wyniku wykonywania obowiązków ze stosunku pracy, b) dokonanych przy pomocy uczelni, c) zamówionych przez uczelnię, d) przeniesionych na rzecz uczelni, e) przekazanych do korzystania przez uczelnię. Regulaminy zawierały postanowienia precyzujące prawa i obowiązki uczelni oraz prawa i obowiązki twórców pracowniczych wyników prac intelektualnych, a także niepracowniczych wyników prac intelektualnych. Nadto w strukturze tychże regulaminów zamieszczano postanowienia szczególne dotyczące: projektów wynalazczych, utworów w rozumieniu prawa autorskiego, programów komputerowych, baz danych. W regulacjach dotyczących kwestii komercjalizacji wyników prac intelektualnych wskazywano, iż wyniki prac intelektualnych uczelni powinny być komercjalizowane w szczególności przez: udzielanie licencji, przenoszenie praw majątkowych, przekazywanie wyników prac intelektualnych w zarząd. Decyzja o komercjalizacji wyników prac intelektualnych i jej formie leżała najczęściej w gestii prorektora ds. nauki, a szczegółowe warunki takiej nalazczość i Ochrona Własności Intelektualnej, Kielce 2010, z. 34, s. 155. 
komercjalizacji były określane każdorazowo w stosownych umowach zawieranych przez uczelnię z podmiotem komercjalizującym te wyniki. Nadto w regulaminach zamieszczano zasady dotyczące wynagrodzeń twórców w sytuacji gdy uczelnia uzyskuje dochód z tytułu korzystania z wyników prac intelektualnych, zasady jego ustalania, terminy i okresy wypłacania, a także wskazywano komu takie wynagrodzenie nie przysługuje (np. osobom zajmującym stanowiska kierownicze w strukturze organizacyjnej uczelni wynagrodzenie nie przysługiwało za projekty racjonalizatorskie) oraz postanowienia dotyczące właściwości organów i jednostek administracyjnych uczelni w sprawach objętych zakresem regulaminu.

W związku z położeniem przez państwo dużego nacisku na politykę innowacyjną w ustawie z dnia 27 lipca 2005 r. Prawo o szkolnictwie wyższym, jeszcze przed jej nowelizacją w 2014 r., umieszczono rozwiązania umożliwiające uczelniom tworzenie akademickich inkubatorów przedsiębiorczości w celu wspierania działalności gospodarczej środowiska akademickiego lub pracowników uczelni i studentów będących przedsiębiorcami (art. 86 ust. 1, 2, 3, 6 i 7 ustawy) oraz centrów transferu technologii mających pośredniczyć w sprzedaży lub nieodpłatnym przekazywaniu wyników badań i prac rozwojowych z uczelni do gospodarki (art. 86 ust. 1, 4, 5, 6 i 7 ustawy). Zarówno akademickie inkubatory przedsiębiorczości, jak i centra transferu technologii mogły być tworzone w formie jednostki ogólnouczelnianej albo w formie spółki handlowej lub fundacji. Mimo tych rozwiązań prawnych, nadal zarówno teoretycy, jak i praktycy wysuwali postulaty tworzenia i rozwijania doskonalszych „narzędzi pomostowych" między nauką (realizowaną głównie przez uczelnie wyższe) a przemysłem i biznesem, które w konsekwencji prowadziłyby do zastosowania i upowszechniania w gospodarce idei nowych produktów i rozwiązań technicznych powstających w uczelniach wyższych, np.: centra zaawansowanych technologii, przedsięwzięcia typu spin-off oraz spin-out, parki naukowo-technologiczne, inkubatory i preinkubatory przedsiębiorczości, projekty uznawane za best practices. ${ }^{17}$

\section{Zmiany stanu prawnego w zakresie organizacji i funkcjonowania praw własności intelektualnej w szkołach wyższych, dokonane nowelą z 2014 r.}

Zmiany te objęly przede wszystkim art. 86 ustawy Prawo o szkolnictwie wyższym. Zgodnie $\mathrm{z}$ dotychczasowym brzmieniem regulacji ustawowych uczelnia, która była właścicielem praw majątkowych do wynalazku swego pracownika, dokonanego w wyniku wykonywania obowiązków ze stosunku pracy, miała prawo do uzyskania patentu na wynalazek stworzony przez jej pracownika, a po jego komer-

17 Szerzej pisze o tym: J. Ożegalska-Trybalska, Działalność innowacyjna i ochrona własności przemysłowej w jednostkach naukowych, (w:) A. Matlak (red.), Zagadnienia prawa własności przemysłowej, „Prace Instytutu Prawa Własności Intelektualnej UJ" 2006, z. 95, s. 137 i n. 
cjalizacji wynalazca otrzymywał udział w zysku zgodnie z postanowieniami umowy zawartej między pracownikiem a uczelnią bądź obowiązującym w uczelni regulaminem własności intelektualnej. Ponieważ, w ocenie twórców projektu nowelizacji ustawy, uczelnie bardzo rzadko rozpoczynają działania zmierzające do komercjalizacji ${ }^{18}$ prac naukowych swoich pracowników, należało wprowadzić takie zmiany w ustawie - Prawo o szkolnictwie wyższym, zgodnie z którymi prawa majątkowe do wynalazku będą należały do pracownika uczelni - twórcy.

Początkowo projekt nowelizacji zakładał pełne „uwłaszczenie naukowców”. Jednak w wyniku prac prowadzonych w komisjach sejmowych i w wyniku tzw. „konsultacji środowiskowych” projektu nowelizacji ustawy - koncepcję tę nieco złagodzono. Aktualnie uchwalona już przez Sejm i przyjęta przez Senat 24 lipca 2014 r. bez poprawek nowelizacja ustawy, która weszła w życie w dniu 1 października 2014 r., w tej kwestii zawiera następujące istotne regulacje. Strony (uczelnia i pracownik uczelni) będą mogły w umowie określić zasady dotyczące praw do wyników badań naukowych lub prac rozwojowych, formy komercjalizacji wynalazków lub efektów badań naukowych, a także zasady podziału środków uzyskanych z ich komercjalizacji. Mają na to trzy miesiące - licząc od dnia przekazania uczelni przez pracownika informacji o wynikach badań naukowych lub prac rozwojowych oraz know-how związanych z tymi wynikami. Jeśli taka umowa nie zostanie zawarta, wówczas będą obowiązywały regulacje zawarte w ustawie. Zgodnie z przepisami ustawy uczelnia wyższa będzie miała 3 miesiące od dnia otrzymania od pracownika informacji o wynikach badań naukowych lub prac rozwojowych oraz know-how związanych z tymi wynikami na podjęcie decyzji czy chce sama komercjalizować wynalazek (art. 86e ust. 1 u.p.o.s.w.).

Po bezskutecznym upływie tego 3-miesięcznego terminu (albo podjęciu przez uczelnię decyzji o niekomercjalizacji) - uczelnia jest zobowiązana, w terminie 30 dni, do złożenia pracownikowi oferty zawarcia bezwarunkowej i odpłatnej umowy o przeniesienie na niego praw do wyników badań naukowych lub prac rozwojowych oraz know-how związanego z tymi wynikami. Umowa musi być zawarta w formie pisemnej pod rygorem nieważności. Wynagrodzenie przysługujące uczelni za przeniesienie praw nie może być wyższe niż $10 \%$ minimalnego wynagrodzenia za pracę, obowiązującego w dniu zawarcia umowy. Pracownik uczelni ma wówczas całkowitą swobodę w wyborze sposobu i formy komercjalizacji oraz instytucji, z którą w tym zakresie podejmie współpracę (art. 86e ust. 2 u.p.o.s.w.). W przypadku nieprzyjęcia przez pracownika oferty zawarcia takiej umowy, prawa do wyników badań nauko-

18 Ustawa Prawo o szkolnictwie wyższym posługuje się terminem „komercjalizacja bezpośrednia” i „komercjalizacja pośrednia”. W art. 2 pkt 35 ustawy ustawodawca definiuje komercjalizację bezpośrednią jako: „sprzedaż wyników badań naukowych, prac rozwojowych lub know-how związanego z tymi wynikami albo oddawanie do używania tych wyników lub know-how, w szczególności na podstawie umowy licencyjnej, najmu oraz dzierżawy”; a w art. 2 pkt 36 ustawy definiuje komercjalizację pośrednią jako: „obejmowanie lub nabywanie udziałów lub akcji w spółkach w celu wdrożenia lub przygotowania do wdrożenia wyników badań naukowych, prac rozwojowych lub know-how związanego z tymi wynikami”. 
wych lub prac rozwojowych oraz know-how przysługują uczelni wyższej (art. 86e ust. 3 u.p.o.s.w.).

W sytuacji gdy komercjalizacji dokonuje uczelnia wyższa pracownikowi przysługuje od uczelni publicznej nie mniej niż: 1) 50\% wartości środków uzyskanych przez uczelnię z komercjalizacji bezpośredniej, obniżonych o nie więcej niż $25 \%$ kosztów bezpośrednio związanych z tą komercjalizacją, które zostały poniesione przez uczelnię lub spółkę celową, 2) 50\% wartości środków uzyskanych przez spółkę celową w następstwie danej komercjalizacji pośredniej, obniżonych o nie więcej niż $25 \%$ kosztów bezpośrednio związanych z tą komercjalizacją, które zostały poniesione przez uczelnię lub spółkę celową (art. 86f ust. 1 pkt 1) i 2) u.p.o.s.w.).

W przypadku komercjalizacji dokonanej przez pracownika, uczelni przysługuje $25 \%$ wartości środków uzyskanych przez pracownika z komercjalizacji, obniżonych o nie więcej niż $25 \%$ kosztów bezpośrednich związanych z tą komercjalizacją, które zostały poniesione przez pracownika. ${ }^{19}$

Stosownie do treści art. 86a ust. 1 ustawy uczelnia, w celu komercjalizacji pośredniej może utworzyć wyłącznie jednoosobową spółkę kapitałową, zwaną „spółką celową". Spółka taka może być także utworzona przez kilka uczelni publicznych albo niepublicznych. Zasada jest taka, iż uczelnia publiczna może przystąpić tylko do spółki celowej utworzonej przez inną uczelnię publiczną, natomiast uczelnia niepubliczna wyłącznie do spółki utworzonej przez inną uczelnię niepubliczną (art. 86b ust. 1 u.p.o.s.w.), a nadto wspólnikami lub akcjonariuszami spółki celowej mogą być tylko uczelnie. W drodze odrębnej (odpłatnej lub nieodpłatnej) umowy uczelnia może powierzyć spółce celowej zarządzanie prawami do wyników prac naukowych lub do know-how w zakresie komercjalizacji bezpośredniej (art. 86a ust. 1 u.p.o.s.w.).

\section{Wnioski końcowe}

Czy istotnie wprowadzone w ustawie Prawo o szkolnictwie wyższym zmiany spowodują w większym wymiarze niż dotychczas szybki i efektywny transfer wyników prac badawczych i rozwojowych z uczelni wyższych do gospodarki, a tym samym spowodują wzrost innowacyjności przedsiębiorstw, czas pokaże. Należy jednak podkreślić, iż w literaturze przedmiotu od wielu lat wskazuje się, że bariery i trudności związane z transferem technologii z nauki do przemysłu są znane. Zalicza się do nich: bariery świadomości i wiedzy, bariery finansowe, małą innowacyjność polskiej nauki, złożoność procesów wdrażania innowacji w przedsiębiorstwach, niedostatek wiedzy na temat zawierania umów o obrót prawami własności intelektualnej. ${ }^{20}$

19 Prawa te przysługują nie dłużej niż przez pięć lat od dnia uzyskania pierwszych środków.

20 Szerzej piszą o tym: A. Szewc i in., Umowy jako prawne narzędzie transferu innowacji, Warszawa 2011 , s. 49 i n. oraz wskazana tam literatura przedmiotu; G. Jyż, Prawo do wynagrodzenia za projekty wynalazcze, Katowice 2003, s. 105 i n.; A. Szewc, G. Jyż, Prawo własności przemysłowej, Warszawa 2011, s. 465 i n. 
Dodać należy, iż uczelnie wyższe do końca marca 2015 r. miały obowiązek uchwalenia przez senaty regulaminów zarządzania prawami autorskimi i prawami pokrewnymi oraz prawami własności przemysłowej oraz zasad ich komercjalizacji (art. 86c ust. 1 pkt 1) u.p.o.s.w.), a także regulaminów korzystania $\mathrm{z}$ infrastruktury badawczej uczelni (art. 86c ust. 1 pkt 2) u.p.o.s.w.). ${ }^{21}$ Nie ma jeszcze pełnych danych, czy ten obowiązek został spełniony w terminie przez wszystkie uczelnie. Nie można również, na tym etapie badań nad tą problematyką, ocenić jakości i zgodności z postanowieniami znowelizowanej ustawy przyjętych przez senaty poszczególnych uczelni wyższych regulaminów, ani tym bardziej ich funkcjonowania w praktyce. Jednak badania tych zagadnień niewątpliwie są godne kontynuowania. 


\section{AMENDMENT OF THE LAW ON HIGHER EDUCATION IN THE ORGANIZATION AND FUNCTIONING OF INTELLECTUAL PROPERTY ISSUES IN HIGHER EDUCATION INSTITUTIONS (SELECTED PROBLEMS)}

This article applies to selected issues related to the amendment of the Act of 27 July 2005. Law on Higher Education in the organization and functioning of intellectual property matters in Polish universities. It analyses the legal solutions designed to cause an increase in the level of use in practice by entrepreneurs (and consequently the country's economy) of research results obtained by universities. Scientific reflection was the creator of the legal situation with the employees of universities wishing to commercialize their intellectual property.

Słowa kluczowe: szkoły wyższe, własność intelektualna, komercjalizacja, innowacyjna gospodarka

Keywords: universities, intellectual property, commercialization, innovative economy 